Poznań

\title{
Kryzys imigracyjny w UE i sposoby jego rozwiazania
}

\begin{abstract}
Streszczenie: Przedmiotem rozważań niniejszego artykułu są zagadnienia związane z działaniami UE w zakresie rozwiązania kryzysu imigracyjnego w okresie od początku 2015 roku do końca pierwszego kwartału 2016 roku. W artykule dokonana została analiza ilościowa zjawiska imigracji do UE. Uwypuklono sytuację w Niemczech ze względu na największe zainteresowanie tym krajem ze strony potencjalnych uchodźców. Rozważaniu poddane zostały także polityka imigracyjna UE oraz działania zmierzające do rozwiązania kryzysu imigracyjnego (w tym relokacja, przesiedlenie, powroty oraz współpraca z państwami pochodzenia imigrantów i tranzytu - Turcją, państwami Bałkanów Zachodnich i Afryki). W artykule pokazano rozłam w państwach członkowskich i tym samym brak solidarności w rozwiązywaniu problemu.
\end{abstract}

Slowa kluczowe: imigranci, uchodźcy, kryzys imigracyjny, relokacja, przesiedlenie, Unia Europejska

ryzys imigracyjny jest największym wyzwaniem, przed którym stoi obecnie UE. Skłonił on instytucje unijne do wzmocnienia wewnętrznej solidarności i odpowiedzialności oraz zwiększenia pomocy państwom najbardziej narażonym na napływ imigrantów. W celu rozwiązania problemów związanych z kryzysem, Rada Europejska zdecydowała o podjęciu działań w trzech kierunkach. Do nich zaliczyła relokację/ przesiedlenia, powroty/readmisję/reintegrację oraz współpracę z państwami pochodzenia i tranzytu. Presja migracyjna, w 2015 i pierwszych miesiącach 2016 roku, była na poziomie dotąd niespotykanym. Społeczeństwa i państwa europejskie nie były na to przygotowane. Coraz głośniej wyrażały swój sprzeciw wobec przyjmowania kolejnych cudzoziemców. Powstały kryzys imigracyjny odsłonił problemy z zachowaniem solidarności i odpowiedzialności wewnątrz Unii Europejskiej.

Badając powyższą problematykę, zasadne wydaje się postawienie kilku pytań badawczych: jakie rozmiary osiagnęła imigracja do państw UE w 2015 roku?, jakie decyzje podjęto na poziomie UE w celu rozwiązania napływu imigrantów?, jakie były reakcje państw na powstały kryzys? oraz czy w obliczu kryzysu udało się zachować jedność i solidarność w ramach państw członkowskich UE? Interdyscyplinarne podejście do badanego zjawiska wymusiło zastosowanie różnych metod badawczych, w tym metody analizy politologicznej, decyzyjnej, statystycznej i komparatystycznej.

W 2015 roku, w ocenie agencji Frontex, dotarło nielegalnie na teren UE 1,83 mln osób (Greece, 2016) ${ }^{1}$. Był to wynik ponad 4 razy większy niż rok wcześniej. Cudzoziemcy zmierzali przede wszystkim do Niemiec, Wielkiej Brytanii i państw skandynawskich. Pochodzili oni najczęściej z państw Afryki Północnej, Wschodniej (Libia, Erytrea, Somalia, Nigeria) oraz Bliskiego Wschodu (Syria, Afganistan).

Do Europy próbowali przedostać się przez Morze Śródziemne do Hiszpanii (tzw. szlak zachodniośródziemnomorski), Grecji (tzw. szlak wschodniośródziemnomorski,

\footnotetext{
${ }^{1}$ Jedna osoba mogła przekraczać granicę więcej niż jeden raz.
} 
głównie Syryjczycy, Afgańczycy) i Włoch (tzw. szlak środkowośródziemnomorski - przede wszystkim obywatele Erytrei, Nigerii i Somalii). Dla innych droga wiodła przez Macedonię, Serbię w kierunku Węgier przez Austrię do Niemiec (szlak zachodniobałkański - najczęściej obywatele Syrii, Afganistanu i Iraku). Jeszcze inni przekraczali granicę rosyjsko-norweską (tzw. szlak murmański - głównie Afgańczycy).

Podróż do Europy była bardzo trudna. Imigranci poruszali się drogą lądową i morską przez Morze Śródziemne. Wielu z nich straciło życie. Wg szacunków w 2015 roku utonęło 3771 osób (w tym 2892 w centralnej części morza, 805 we wschodniej, a 74 osoby w zachodniej części - Mapa 1). Najtragiczniejszy na morzu był kwiecień i sierpień. Wówczas zginęło 1244 osoby i 686 osób. Dane szacunkowe IOM wskazują, że w ciagu 12 miesięcy ubiegłego roku zmarło ponad 5350 imigrantów (Over, 2015).

\section{Mapa 1. Liczba imigrantów, która przybyła przez Morze Śródziemne do państw UE i utonęla w 2015 roku}

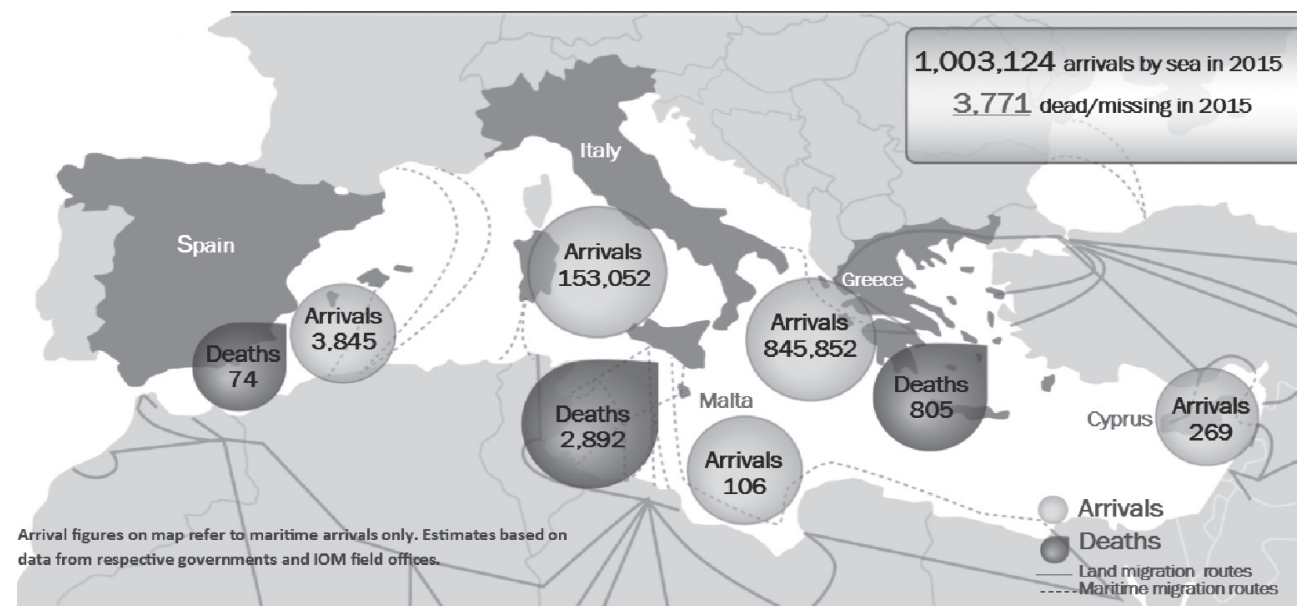

Źródlo: Over 3,770 Migrants Have Died Trying to Cross the Mediterranean to Europe in 2015 (2015), IOM, http:/www.iom.int/news/over-3770-migrants-have-died-trying-cross-mediterranean-europe-2015, 5.02.2016.

W odpowiedzi na niekontrolowany napływ cudzoziemców niektóre państwa podejmowały decyzję o: stawianiu płotów na granicach (Węgry, Słowenia, Austria, Macedonia), wprowadzeniu tymczasowych kontroli granicznych (Niemcy, Dania, Szwecja, Austria, Słowenia, Chorwacja), obniżeniu zasiłków dla uchodźców (Szwecja, Dania, Walia, Litwa, Norwegia, Holandia) oraz konfiskacie majątków imigrantów na poczet ich utrzymania (Dania, Szwajcaria, Bawaria i Badenia Wirtembergia w Niemczech). W wielu miastach europejskich dochodziło do protestów zwolenników i przeciwników pomocy imigrantom. Liczne były także ataki na ośrodki dla uchodźców. Na przykład w Niemczech doszło do 173 takich czynów w 2015 roku, podczas gdy rok wcześniej odnotowano 28 takich przypadków. Wzrosła ponadto liczba podpaleń w Niemczech (z 6 do 92 w 2015 roku) oraz przestępstw przeciwko uchodźcom (z 199 do 1005 w 2015 roku - Coraz więcej, 2016). W lokalnych społecznościach swój sprzeciw wobec imigrantów wyrażano także poprzez wprowadzanie zakazu wstępu do baru (Bad Ischl w Austrii), klubów w Danii, na baseny 
(Bornheim w Niemczech, Koksijde w Belgii). W Niemczech (Dolnej Saksonii, Meklemburgii Pomorzu Przednim) i Finlandii tworzono „straże obywatelskie”.

Według sondażu przeprowadzonego na zlecenie Parlamentu Europejskiego w 28 państwach członkowskich we wrześniu 2015 roku (czyli przed zamachami w Paryżu) zagadnienie imigracji znalazło się na drugim miejscu (przed walką z bezrobociem) wśród wyzwań stojących przed UE (Główne wyzwania, 2015). Tak uznało 47\% badanych (ibidem, s. 2). Większość (66\%) opowiedziała się za wspólnymi działaniami na poziomie UE w zakresie polityki migracyjnej oraz wsparciem finansowym państw członkowskich najbardziej narażonych na napływ imigrantów (62\% - ibidem, s. 4). Obywatele UE uznali ponadto, że procedury dotyczące legalnej migracji powinny być „takie same” dla wszystkich państw członkowskich (79\% - ibidem, s. 4). W ich ocenie rozlokowanie osób ubiegających się o status uchodźcy powinno być lepiej rozłożone między państwami członkowskim $(78 \%)^{2}$, a decyzje w tej sprawie winny zapadać na szczeblu UE na podstawie „wiążących kwot” (78\% - ibidem, s. 5).

Mimowolne migracje ludności na dużą skalę zostały uznane także przez światowych ekspertów Forum Ekonomicznego za najważniejsze wyzwanie stojące przed światem w ciaggu najbliższych 18 miesięcy (The Global, 2016, s. 13). Dotyczyło to także perspektywy regionalnej czyli kontynentu europejskiego (ibidem, s. 5). Na liście prawdopodobnych zagrożeń globalnych w 2016 roku migracje uplasowały się na pierwszym miejscu (pierwszy raz od 2007 roku, ibidem, s. 11).

Unia Europejska, jak pokazały wydarzenia z ostatnich miesięcy, nie miała sprawnie działającej polityki imigracyjnej. Jej podstawą prawną są artykuły 79 i 80 Traktatu o funkcjonowaniu Unii Europejskiej (Wersje skonsolidowane, 2012). Zgodnie z artykułem 80, polityka imigracyjna UE opiera się na zasadzie „solidarności i sprawiedliwego podziału odpowiedzialności między Państwami Członkowskimi, w tym również na płaszczyźnie finansowej” (ibidem). Przepis ten w obliczu napływu imigrantów w 2015 roku stał się podstawą domagania się solidarności w sprawie ich podziału między państwa członkowskie UE.

Europejska polityka imigracyjna ma wymiar wewnętrzny i zewnętrzny. Pierwszy obejmuje zagadnienia legalnej i nielegalnej migracji (walka z przemytem ludzi), granic, wiz, wspólnego europejskiego systemu azylowego. Drugi określony został w programie zatytułowanym „Globalne podejście do kwestii migracji i mobilności” (GAMM) z 2005 roku (Global, 2016). Dotyczy on współpracy UE z państwami trzecimi w dziedzinie migracji. GAMM realizowany jest poprzez szereg inicjatyw mających wymiar kontynentalny (np. partnerstwo UE-Afryka na rzecz migracji), jak i regionalny (np. dialog w zakresie migracji UE-państwa Afryki Subsaharyjskiej, UE-Ameryka Łacińska i Karaiby, Partnerstwo Wschodnie, Proces Praga, Proces Budapeszt).

Wzrost liczby osób aplikujących o status uchodźcy w państwach UE zauważalny był od 2012 roku. Przyrost ten do końca 2013 roku nie był jednak tak spektakularny, jak

${ }^{2}$ Poparcie dla odpowiedzi na pytanie „czy liczba osób ubiegających się o azyl powinna być lepiej rozdzielona pomiędzy wszystkie państwa członkowskie UE" różniło się w poszczególnych państwach. Na przykład w Niemczech odpowiedzi twierdzących udzieliło 97\% badanych, podobnie jak w Szwecji - 94\%. Natomiast na Słowacji i w Czechach tego zdania było tylko 31\% i 33\% respondentów. Główne wyzwania dla UE, migracja oraz sytuacja gospodarcza i społeczna, Parlametr 2015 - część I (2015), Bruksela 14.10.2015 r., Eurobarometr Parlamentu Europejskiego (EB/EP 84.1), s. 5, http://www.europarl.europa.eu/pdf/eurobarometre/2015/2015parlemeter/EB84.1_synt_conso_pl.pdf, 2.02.2016. 
z 2014 na 2015 rok. Wówczas liczba wnioskujących wzrosła z 627780 do 1255640 osób (Wykres 1).

\section{Wykres 1. Osoby aplikujące o status uchodźcy w państwach UE w latach 2008-2015}

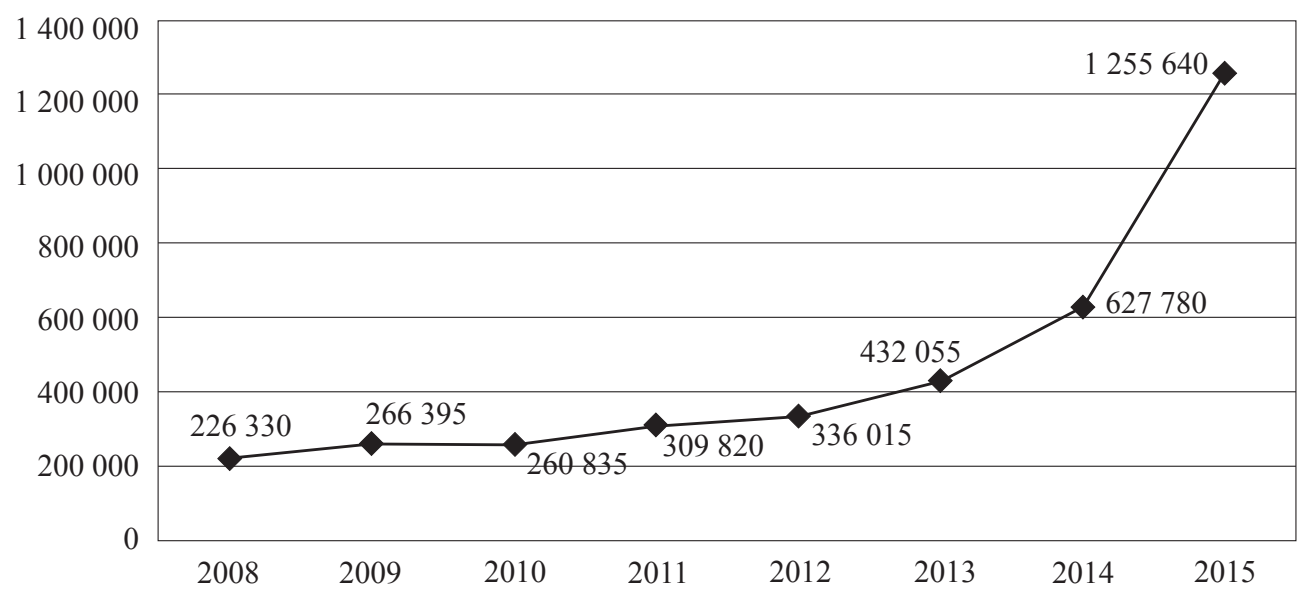

Źródło: Opracowanie własne na podstawie Asylum and new asylum applicants - annual aggregated data (2016a), Eurostat, http://ec.europa.eu/eurostat/tgm/table.do?tab=table\&init=1\&plugin=1\&pcode=tps00191\&language=en, 17.02.2016, Asylum in the EU Member States Record number of o ver 1.2 million first time asylum seekers registered in 2015. Syrians, Afghans and Iraqis: top citizenship, Eurostat Newesrelease (2016c), 44/2016, 4 March 2016, Eurostat, http://ec.europa.eu/eurostat/documents/2995521/7203832/304032016-AP-EN.pdf/790eba01-381c-4163-bcd2-a54959b99ed6, 20.03.2016.

W 2015 roku, kiedy UE zmagała się z problemem imigracyjnym, największy wzrost osób ubiegających się o status uchodźcy nastąpił między styczniem a lutym o ponad 64 000, a największy spadek odnotowano w miesiącach zimowych między listopadem a grudniem (o prawie 72000 osób - Wykres 2).

W latach 2008-2011 największym powodzeniem wśród państw członkowskich UE, w których cudzoziemcy ubiegali się o status uchodźcy cieszyła się Francja. Na drugim miejscu uplasowały się Niemcy, które w kolejnych latach wiodły prym w tej dziedzinie. W 2015 roku, poza Niemcami, najwięcej wniosków złożono na Węgrzech (174 435 - 14\% wszystkich aplikacji na terenie UE), w Szwecji (156 110 - 12\%) oraz Austrii i Włoszech (po 7\%, Asylum, 2016c, s. 2). Należy jednocześnie zauważyć, iż w 2015 roku w stosunku do 2014 największy wzrost osób aplikujących o status uchodźcy na poziomie krajowym odnotowano w: Finlandii (o 822\%), Wegrzech (o 323\%), Austrii (o 233\%) i Belgii (o 178\%, ibidem).

W 2015 roku Niemcy były państwem, które przyjęło najwięcej imigrantów. Łącznie o azyl wnioski złożyło 476649 cudzoziemców. Liczba ta była największa od 1995 roku, a w stosunku do roku poprzedniego wzrosła o ponad 100\% (Aktuelle, 2016, s. 4). Od stycznia do sierpnia 2015 roku liczba wnioskodawców oscylowała między 25000 a 37 000, a we wrześniu wzrosła do ponad 43 000. Najwięcej cudzoziemców o azyl aplikowało w listopadzie 2015 roku (57 816 osób - Asylgeschäftsstatistik, 2015, s. 11). Wzrost zainteresowania Niemcami miał związek z przesłaniem kanclerz Ange- 
li Merkel zawartym w słowach „Wir schaffem das!” wypowiedzianych we wrześniu 2015 roku. Ta otwartość przysporzyła Niemcom popularność wśród potencjalnych uchodźców.

Wykres 2. Osoby aplikujące o status uchodźcy w państwach UE od stycznia do grudnia 2015 roku

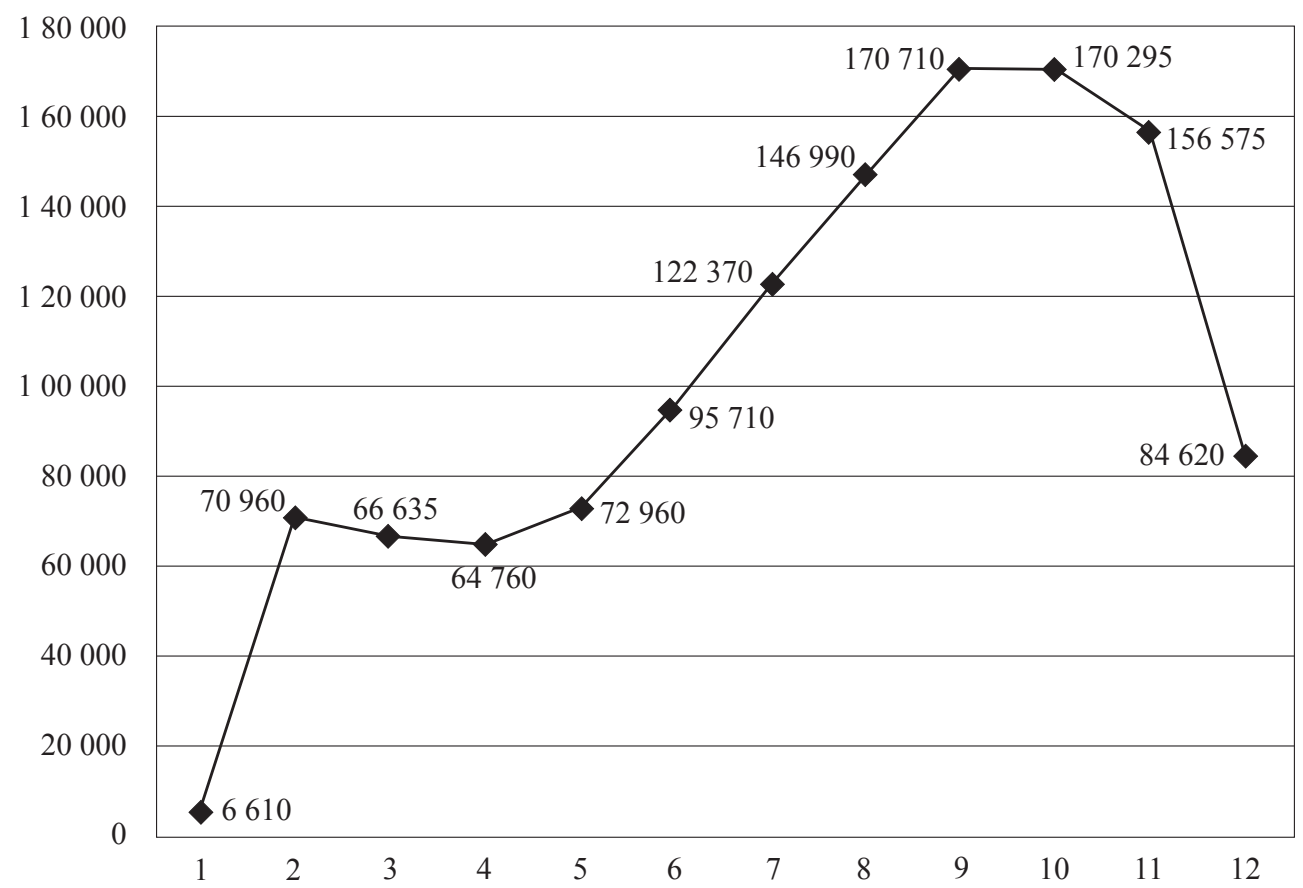

Źródło: Opracowanie własne na podstawie Asylum and first time applicants by citizenship, age and sex Monthly data (2016b), Eurostat, http://appsso.eurostat.ec.europa.eu/nui/show.do, http://appsso.eurostat.ec.europa.eu/nui/show.do, 17.02.2016.

Ogromna fala imigrantów zmierzająca i przybyła do Niemiec miała wpływ na decyzje o przywróceniu kontroli na granicy z Austrią oraz zaostrzeniu prawa azylowego. W trudnej sytuacji znalazła się Bawaria, która była drugim w kolejności landem przyjmującym najwięcej wniosków o azyl (71 168 w 2015 roku, podczas gdy Nadrenia Północna Westfalia 77223 - Asylgeschäftsstatistik, 2015, s. 5). Premier Bawarii Horst Seehofer krytycznie odnosił się do polityki proimigracyjnej kanclerz Niemiec (tzw. Willkommenspolitik). Był gotów złożyć skargę na rząd do Federalnego Trybunału Konstytucyjnego. Opowiadał się za wprowadzeniem limitów imigracyjnych w Niemczech i UE, uruchomieniem hot spotów na granicy nieniecko-austriackiej w celu rejestracji przybyszy, a także kontrolą granic zewnętrznych UE. Zdesperowany wysłał autokarem do kanclerz imigrantów, których nie miał gdzie ulokować.

$\mathrm{Na}$ terenie Niemiec do dystrybucji uchodźców wykorzystuje się system kwotowy (tzw. Königsteiner Schlüssel). Na jego podstawie w danym landzie liczba imigrantów ubiegająca się o status uchodźcy obliczana jest na podstawie wpływów podatkowych i liczby ludności każdego landu co roku (Mapa 2). 
Mapa 2. Rozdział imigrantów z wykorzystaniem systemu kwotowego między niemieckie landy w 2016 roku

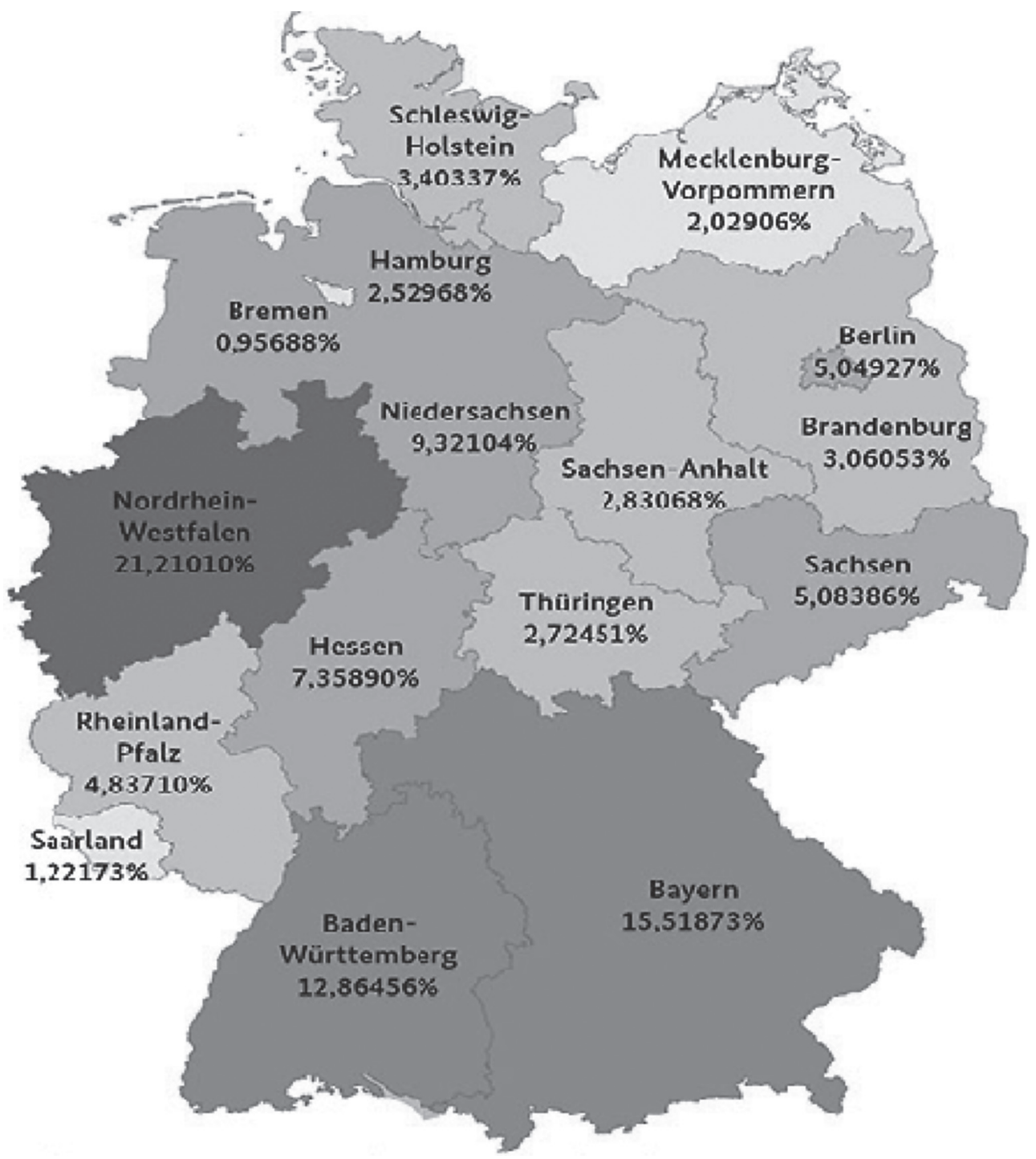

Źródło: „Königsteiner Schlüssel”, http://www.bamf.de/DE/Migration/AsylFluechtlinge/Asylverfahren/Verteilung/verteilung-node.html, 3.03.2016.

Wśród imigrantów aplikujących o status uchodźcy, w 2015 roku na terenie UE, najczęściej byli obywatele Syrii, Afganistanu i Iraku. Na łączną liczbę 1255640 wnioskodawców pierwsi stanowili $29 \%$, drudzy 14\%, a trzeci 10\% (Asylum, 2016c, s. 3). Ochrony szukali przede wszystkim w Niemczech, Szwecji i na Węgrzech.

Z badań przeprowadzonych między 8 października 2015 roku a 2 lutego 2016 roku przez pracowników Międzynarodowej Organizacji ds. Migracji (IOM) w Chorwacji, Macedonii, Grecji i Słowenii wynikało, iż przeciętny Syryjczyk był w wieku 28 lat. 
W 74\% byli to mężczyźni. Większość z nich podróżowała do Europy w grupach (87\%) wraz z innymi członkami rodziny (73\% - Flow, 2016, s. 38). Byli oni dobrze wykształceni - 40\% skończyła studia, a 44\% liceum (ibidem, s. 39). Większość z nich (98\%) nie mieszkała wcześniej w obozie dla uchodźców. Ich miejscem przeznaczenia były przede wszystkim Niemcy $(75 \%$ - ibidem, s. 39). Niewielki procent chciał dotrzeć do Szwecji (7\%) i Holandii (4\%). W kraju przeznaczenia aż 64\% badanych miało rodzinę, a $35 \%$ nie posiadała krewnych (ibidem, s. 40). Poza Syryjczykami drugą co do wielkości grupą przebadaną przez pracowników IOM byli obywatele Afganistanu. Byli oni młodsi od Syryjczyków i mieli na ogół 24 lata. W $86 \%$ byli mężczyznami podróżującymi najczęściej w grupach (83\%). Jedynie 17\% z nich wędrowała samotnie (ibidem, s. 40). 21\% Afgańczyków ukończyło studia, 49\% szkołę średnią, a 23\% naukę na poziomie szkoły podstawowej (ibidem, s. 41). Podobnie, jak Syryjczycy również i Afgańczycy nie mieszkali wcześniej w obozach uchodźczych (98\%). Chcieli oni dotrzeć do Niemiec $(60 \%)$ i Szwecji (11\% - ibidem). W państwach docelowych 42\% miało krewnych, a 58\% nie. Kolejną nacja, poza obywatelami Syrii i Afganistanu, byli Irakijczycy. Ich charakterystyka była bardzo zbliżona do poprzednich narodowości. Oznacza to, że byli oni przede wszystkim mężczyznami (85\%) na ogół w wieku 29 lat, podróżującymi częściej w grupie $(88 \%)$, niż samotnie ( $12 \%$ ibidem, s. 42 ). Wcześniej nie przebywali w obozach dla uchodźców (94\%) i zamierzali, jak pozostali dotrzeć do Niemiec (68\%) i Szwecji (7\%). Wyróżniał ich jednak fakt słabszego wykształcenia od pozostałych ww. grup narodowościowych (55\% ukończyła szkołę podstawową, 28\% studia, a 13\% szkołę średnią - ibidem, s. 43).

W obliczu wyzwań, jakie niósł za sobą napływ imigrantów do UE podjęto szereg inicjatyw mających na celu rozwiązanie tego problemu. Wśród nich znalazły się między innymi przesiedlenia, relokacja i powroty nielegalnych imigrantów. Pierwsza z propozycji nie była nowa. Działania związane z przesiedleniem uchodźców z państw trzecich do członkowskich UE podjęto już w 2005 roku. Wówczas związane były one z przyjęciem programu haskiego, w którym zaproponowano regionalne programy ochrony (Program Haski, 2005). Ich partnerami miały być państwa UE i wybrane kraje trzecie. Przesiedlenia określono jako główny element pomocy tym krajom w ochronie uchodźców. Inne działania miały wymiar instytucjonalny. W ramach tej aktywności uruchomiono w 2008 roku Nowy Europejski Fundusz na rzecz Uchodźców (Decyzja, 2007), a dwa lata później Europejski Urząd Wsparcia w dziedzinie Azylu (Rozporzq̨dzenie, 2010). Do przesiedleń odwołano się w planie polityki azylowej z 2008 roku (Komunikat, 2008), wspólnym unijnym programie przesiedleń (Komunikat, 2009) oraz rezolucji Parlamentu Europejskiego z dnia 18 maja 2010 roku (Rezolucja, 2010). W dniu 8 czerwca 2015 roku zaakceptowano Europejski Program Przesiedleń (Zalecenie, 2015). Na jego podstawie zalecono przemieszczenie na teren UE 20000 osób potrzebujących ochrony międzynarodowej (szczególnie z Afryki Północnej, Bliskiego Wschodu, Rogu Afryki i państw, w których realizowane były regionalne programy rozwoju i ochrony). Czas trwania programu określono na dwa lata od dnia przyjęcia zalecenia. Krajom przyjmującym zapewniono środki finansowe proporcjonalnie do liczby przyjętych. Stwierdzono, że przyszły podział osób „wyraźnie potrzebujących ochrony międzynarodowej” powinien opierać się na:
„a) wielkości populacji (współczynnik ważenia 40\%),
b) całkowitym PKB (współczynnik ważenia 40\%), 
c) średniej liczbie spontanicznych wniosków o udzielenie azylu i liczbie przesiedlonych uchodźców na 1 mln mieszkańców w latach 2010-2014 (współczynnik ważenia 10\%),

d) stopie bezrobocia (współczynnik ważenia 10\%)" (pkt 9, Zalecenie, 2015).

Do dokumentu dołączono załącznik z podziałem 20000 osób między poszczególne państwa członkowskie. Najwięcej ich przyznano Niemcom, Francji i Wielkiej Brytanii (w kolejności: 3086, 2375, 2309 osób). Polsce zaproponowano 962 osoby (ibidem, Zatacznik).

Poza przesiedleniami innym sposobem rozwiązania problemu napływu imigrantów była ich relokacja. Polega ona na wewnątrzunijnym transferze uchodźców z jednego do drugiego państwa członkowskiego UE. Pierwszy projekt (EUREMA) w ramach relokacji zatwierdzono w czerwcu 2009 roku. Zakładał on przejęcie cudzoziemców z Malty. Realizowany był on w dwóch fazach w 2011 i 2012 roku. W pierwszej edycji do relokacji zakwalifikowano 253-255 imigrantów, z których przeniesiono do innych państw członkowskich 227 osób (EASO, 2012, s. 6). Najwięcej z nich przyjęły Niemcy (102 osoby) i Francja (95 osób). Z kolei do drugiej fazy włączono 356 osób (ibidem). Polska była uczestnikiem tego projektu i w pierwszej jego części zadeklarowała przyjęcie 6 , a w drugiej 50 cudzoziemców. Z propozycji naszej skorzystało jedynie 6 osób (5 Somalijczyków i 1 Erytrejczyk - EUREMA II, 2013). Geneza tych działań miała swoje źródło w art. 78 ust. 3 Traktatu o funkcjonowaniu Unii Europejskiej. Stanowi on, że „w przypadku gdy jedno lub więcej państw członkowskich znajdzie się w nadzwyczajnej sytuacji charakteryzującej się nagłym napływem obywateli państw trzecich, Rada, na wniosek Komisji, może przyjąć środki tymczasowe na korzyść zainteresowanego państwa lub państw członkowskich. Rada przyjmuje te środki po konsultacji z Parlamentem Europejskim" (Wersje skonsolidowane, 2012).

Na podstawie ww. regulacji prawnej państwa członkowskie UE podjęły stosowne działania. Jednym z pierwszych było opracowanie 10-punktowego planu będącego odpowiedzią na pogłębiający się kryzys (Joint Foreign, 2015). Przyjęto go 20 kwietnia 2015 roku w Luksemburgu na wspólnym posiedzeniu Rady do Spraw Zagranicznych i Rady do Spraw Wewnętrznych. Był on reakcją na tragiczną sytuację w basenie Morza Sródziemnego. Plan ten przewidywał:

- wzmocnienie wspólnych działań na Morzu Śródziemnym (Triton, Posejdon) poprzez zwiększenie na to środków finansowych oraz poszerzanie obszaru operacyjnego;

- systematyczne przeciwdziałanie aktywności przemytników w basenie Morza Śódziemnego (np. operacja Atlanta);

- zaciśnięcie współpracy między takimi instytucjami, jak: EUROPOL, FRONTEX, EASO i EUROJUST w celu zebrania niezbędnych informacji o aktywności przemytników;

- zaangażowanie przez Europejski Urząd Wsparcia w dziedzinie Azylu zespołów do wspólnego rozpatrywania wniosków o ochronę międzynarodową w Grecji i we Włoszech;

- zobowiązanie państw członkowskich do pobierania odcisków palców wszystkim imigrantom;

- rozważenie możliwości wprowadzenia mechanizmu relokacji;

- stworzenie dobrowolnego projektu UE w sprawie przesiedleń dla osób potrzebujących ochrony; 
- przygotowanie nowego programu powrotu nielegalnych imigrantów;

- podjęcie wspólnych wysiłków Komisji i Europejskiej Służby Działań Zewnętrznych na rzecz otaczających Libię państw i wzmocnienie inicjatyw w Nigerii;

- zaangażowanie oficerów łącznikowych ds. imigracji (ILO) w kluczowych państwach trzecich do zbierania informacji na temat przepływów imigracyjnych do UE oraz wzmocnienie delegatur UE (ibidem).

Po przyjęciu 10-punktowego planu dalsza aktywność w dziedzinie imigracji została określona w oświadczeniu wydanym przez Radę Europejską (w części zatytułowanej „Wzmocnić wewnętrzną solidarność i odpowiedzialność”) w dniu 23 kwietnia 2015 roku. Zapowiedziano w nim między innymi prace na rzecz skutecznego wdrożenia europejskiego systemu azylowego, pomocy państwom członkowskim najbardziej narażonym na napływ imigrantów oraz organizacji relokacji i przesiedleń (Nadzwyczajne, 2015). Odwołanie się do pomocy państwom członkowskim z największą liczbą wnioskujących o status uchodźcy miało miejsce również w treści rezolucji wydanej przez Parlament Europejski w dniu 28 kwietnia 2015 roku.

W związku z narastającym kryzysem imigracyjnym w UE przygotowano europejski program w zakresie migracji (Komunikat, 2015). Związany był on z pomocą państwom najbardziej narażonym na napływ nielegalnych imigrantów szukających w UE schronienia, ale także z przesiedleniem ich z tych państw (Włoch, Grecji, a potem Węgier). W załączniku do tego dokumentu określono kryteria podziału uchodźców między państwami członkowskimi oraz poinformowano o podjęciu działań na rzecz przyjęcia europejskiego programu przesiedleń dla 20000 osób. Tego samego miesiąca Komisja Europejska przyjęła pierwsze konkretne rozwiązania w ramach europejskiego programu w zakresie migracji (Postęp, 2015). Wśród propozycji dotyczących relokacji znalazły się:

- transfer obywateli Syrii i Erytrei wymagających międzynarodowej ochrony, którzy przybyli do Włoch bądź Grecji po 15 kwietnia 2015 roku lub przybędą tam po uruchomieniu tego mechanizmu;

- przemieszczenie 40000 osób do innych państw członkowskich UE w oparciu o klucz podziału w ciagu dwóch lat;

- przekazanie 6000 euro na każdą relokowaną osobę.

Z kolei w zakresie przesiedleń zaproponowano:

- przemieszczenie 20000 osób spoza UE w ciagu dwóch lat;

- uznanie osób podlegających przemieszczeniu przez Wysokiego Komisarza Narodów Zjednoczonych ds. Uchodźców za wymagające międzynarodowej ochrony;

- podział ww. osób wg odpowiedniego klucza;

- wsparcie finansowe w wysokości 50 milionów euro w latach 2015-2016 dla państw członkowskich UE uczestniczących w tym systemie (ibidem).

Tabela 1

Relokacja i przesiedlenia spoza UE na podstawie decyzji Komisji Europejskiej z 27 maja 2015 roku

\begin{tabular}{|c|c|c|c|}
\hline \hline Państwo & Relokacja z Wloch & Relokacja z Grecji & Przesiedlenia \\
\hline 1 & 2 & 3 & 4 \\
\hline Austria & 728 & 485 & 444 \\
\hline
\end{tabular}




\begin{tabular}{|c|c|c|c|}
\hline 1 & 2 & 3 & 4 \\
\hline Belgia & 818 & 546 & 490 \\
\hline Bułgaria & 343 & 229 & 216 \\
\hline Chorwacja & 448 & 299 & 315 \\
\hline Cypr & 104 & 69 & 69 \\
\hline Estonia & 443 & 295 & 326 \\
\hline Finlandia & 475 & 317 & 293 \\
\hline Francja & 4051 & 2701 & 2375 \\
\hline Hiszpania & 2573 & 1715 & 1549 \\
\hline Litwa & 302 & 201 & 207 \\
\hline Luksemburg & 221 & 147 & 147 \\
\hline Lotwa & 310 & 207 & 220 \\
\hline Malta & 175 & 117 & 121 \\
\hline Holandia & 1228 & 819 & 732 \\
\hline Niemcy & 5258 & 3505 & 3086 \\
\hline Polska & 1595 & 1064 & 962 \\
\hline Portugalia & 1021 & 680 & 704 \\
\hline Republika Czech & 797 & 531 & 525 \\
\hline Rumunia & 1023 & 682 & 657 \\
\hline Słowacja & 471 & 314 & 319 \\
\hline Słowenia & 297 & 198 & 207 \\
\hline Szwecja & 821 & 548 & 491 \\
\hline Węgry & 496 & 331 & 307 \\
\hline Włochy & - & - & 1989 \\
\hline Wielka Brytania & - & - & 2309 \\
\hline Dania & - & - & 345 \\
\hline Grecja & - & - & 323 \\
\hline Irlandia & - & - & 272 \\
\hline Razem & 24000 & 16000 & 20000 \\
\hline
\end{tabular}

Źródło: Postęp w realizacji unijnego programu w zakresie migracji (2015), Bruksela 27.05.2015 r., http:// europa.eu/rapid/press-release IP-15-5039 pl.htm, 8.02.2016.

W czerwcu 2015 roku Rada Europejska zatwierdziła dalsze prace nad wnioskami przedstawionymi przez Komisję Europejską w ramach europejskiego programu w zakresie migracji, koncentrując się na relokacji i przesiedleniu, powrocie uchodźców oraz współpracy z krajami ich pochodzenia i tranzytu (Konkluzja, 2015). Zgodę na wprowadzenie czasowych i wyjątkowych mechanizmów relokacji osób „wyraźnie potrzebujących ochrony międzynarodowej” wyraziła Rada ds. Wymiaru Sprawiedliwości i Spraw Wewnętrznych w dniu 20 lipca 2015 roku (Rada ds. Wymiaru, 2015). Na początku zaplanowano relokację 32256 osób w ciąu dwóch lat (Tabela 2). Decyzję w sprawie pozostałych 7744 imigrantów ministrowie zobowiązali się podjać do grudnia 2015 roku. Państwa członkowskie porozumiały się także w sprawie przesiedlenia 22504 osób potrzebujących ochrony międzynarodowej (co oznaczało wzrost o 2504 przesiedleńców w stosunku do decyzji z dnia 27 maja 2015 roku). 
Relokacja z Włoch i Grecji osób wymagających ochrony międzynarodowej do innych państw UE oraz przesiedlenia osób spoza UE na podstawie rezolucji z dnia 20 lipca 2015 roku

\begin{tabular}{|l|r|r|}
\hline & Relokacja z Wloch i Grecji & Przesiedlenia spoza UE \\
\hline Austria & 0 & 1900 \\
\hline Belgia & 1364 & 1100 \\
\hline Bułgaria & 450 & 50 \\
\hline Chorwacja & 400 & 150 \\
\hline Cypr & 173 & 69 \\
\hline Dania & 0 & 1000 \\
\hline Estonia & 130 & 20 \\
\hline Finlandia & 792 & 293 \\
\hline Francja & 6752 & 2375 \\
\hline Grecja & 0 & 354 \\
\hline Hiszpania & 1300 & 1449 \\
\hline Irlandia & 600 & 520 \\
\hline Islandia & - & 50 \\
\hline Lichtenstein & - & 20 \\
\hline Litwa & 255 & 70 \\
\hline Luksemburg & 320 & 30 \\
\hline Lotwa & 200 & 50 \\
\hline Malta & 60 & 14 \\
\hline Holandia & 2047 & 1000 \\
\hline Niemcy & 10500 & 1600 \\
\hline Norwegia & - & 3500 \\
\hline Polska & 1100 & 900 \\
\hline Portugalia & 1309 & 191 \\
\hline Republika Czech & 1100 & 400 \\
\hline Rumunia & 1705 & 80 \\
\hline Słowacja & 100 & 100 \\
\hline Słowenia & 230 & 20 \\
\hline Szwajcaria & - & 519 \\
\hline Szwecja & 1369 & 491 \\
\hline Węgry & 0 & 0 \\
\hline Włochy & - & 1989 \\
\hline Wielka Brytania & - & 2200 \\
\hline Razem & 32256 & 2204 \\
\hline & & \\
\hline
\end{tabular}

Źródło: Outcome of the Council Meeting. 3405th Council meeting Justice and Home Affairs, Brussels, 20 July 2015, Council of the European Union 11097/15, s. 4-5, 7-8.

Kolejne działania w sprawie rozwiązania kryzysu imigracyjnego podjęto we wrześniu 2015 roku. Pierwszym z nich było zaproponowanie przez Komisję Europejską drugiego pakietu środków mających rozwiązać powstały kryzys (9 września). W ramach tego projektu zainicjowano między innymi relokację w sytuacjach nadzwyczajnych 120000 osób ,wyraźnie potrzebujących ochrony międzynarodowej” z Włoch, Grecji i Węgier (Decyzja, 9.09.2015). W pierwszym z wymienionych państw dotyczyło to 15600 imigrantów, w drugim - 50 400, a w trzecim 54000 osób (Tabela 3). Poza tym, określono także procedury relokacji, prawa i obowiązki wnioskodawców objętych decyzją o relokacji, środki uzupełniające podejmowane wobec ww. trzech państw, jak i wsparcie finansowe (na każdą osobę relokowaną 6000 euro oraz ryczałtowo 500 euro na przebywającą na obszarze Włoch, Grecji i Wegier). Łączny koszt realizacji powyższych działań oszacowano na kwotę 780000000 euro (ibidem). 
Relokacja na podstawie decyzji Komisji Europejskiej z dnia 9 września 2015 roku

\begin{tabular}{|l|r|r|r|r|}
\hline \multicolumn{1}{|c|}{ Państwo } & $\begin{array}{c}\text { Relokacja } \\
\text { z Wloch }\end{array}$ & $\begin{array}{c}\text { Relokacja } \\
\text { z Grecji }\end{array}$ & $\begin{array}{c}\text { Relokacja } \\
\text { z Węgier }\end{array}$ & Razem \\
\hline Austria & 473 & 1529 & 1638 & 3640 \\
\hline Belgia & 593 & 1917 & 2054 & 4564 \\
\hline Bułgaria & 208 & 672 & 720 & 1600 \\
\hline Chorwacja & 138 & 447 & 479 & 1064 \\
\hline Cypr & 36 & 115 & 123 & 274 \\
\hline Estonia & 48 & 157 & 168 & 373 \\
\hline Finlandia & 312 & 1007 & 1079 & 2398 \\
\hline Francja & 3124 & 10093 & 10814 & 24031 \\
\hline Hiszpania & 1941 & 6271 & 6719 & 14931 \\
\hline Litwa & 101 & 328 & 351 & 780 \\
\hline Luksemburg & 57 & 185 & 198 & 440 \\
\hline Lotwa & 68 & 221 & 237 & 526 \\
\hline Malta & 17 & 56 & 60 & 133 \\
\hline Holandia & 938 & 3030 & 3246 & 7214 \\
\hline Niemcy & 4088 & 13206 & 14149 & 31443 \\
\hline Polska & 1207 & 3901 & 4179 & 9287 \\
\hline Portugalia & 400 & 1291 & 1383 & 3074 \\
\hline Republika Czech & 387 & 1251 & 1340 & 2978 \\
\hline Rumunia & 604 & 1951 & 2091 & 4646 \\
\hline Słowacja & 195 & 631 & 676 & 1502 \\
\hline Słowenia & 82 & 265 & 284 & 631 \\
\hline Szwecja & 581 & 1877 & 2011 & 4469 \\
\hline Razem & 15600 & 50400 & 54000 & 120000 \\
\hline
\end{tabular}

Źródło: Opracowanie własne na podstawie Załaczniki towarzyszace wnioskowi dotyczacemu decyzji Rady wprowadzajqcej środki przejściowe w dziedzinie ochrony międzynarodowej na korzyść Wtoch, Grecji i Węgier (2015), Bruksela 9.09.2015r., http://ec.europa.eu/dgs/home-affairs/what-we-do/policies/european-agenda-migration/proposal-implementation-package/docs/proposal_for_council_decision_establishing_provisional_measures_in_the_area_of_international_protection_for_it_gr_and_hu_-_annexe_pl.pdf, 5.03.2016.

14 września 2015 roku Rada ds. Wymiaru Sprawiedliwości i Spraw Wewnętrznych przyjęła ostateczną decyzję w sprawie relokacji. Wiązała się ona z transferem 40000 osób wymagających ochrony międzynarodowej z Włoch (24 000) i Grecji (16 000) do innych państw członkowskich UE - Decyzja, 14.09.2015). Dokument ten wynikał z rezolucji przedstawicieli rządów państw z dnia 20 lipca 2015 roku. Określono w nim procedury relokacji, prawa i obowiązki wnioskujących o ochronę międzynarodową oraz potwierdzono wsparcie finansowe dla państw członkowskich przyjmujących relokujących w wysokości 6000 euro na osobę. Następnie członkowie tej samej rady, w dniu 22 września 2015 roku, przyjęli decyzję o relokacji imigrantów z Włoch i Grecji (Decy$z j a, 22.09 .2015)$. Została on zaaprobowana przy sprzeciwie Rumunii, Węgier, Słowacji i Czech oraz głosie wstrzymującym Finlandii. Na podstawie tej decyzji relokacją, do 26 września 2017 roku, objęto 120000 osób, w tym z Włoch (15 600) i Grecji (50 400 - Tabela 4). Niniejsza decyzja dotyczyła osób przybywających na terytorium ww. państw od dnia 25 września 2015 roku do dnia 26 września 2017 roku oraz wnioskodawców, którzy przybyli na terytorium Włoch i Grecji od dnia 24 marca 2015 roku (art. 13 ust. 3). 
Relokacja na podstawie decyzji Rady UE z dnia 22 września 2015 roku

\begin{tabular}{|l|r|r||}
\hline \multicolumn{1}{|c|}{ Państwo } & Relokacja z Wloch & Relokacja z Grecji \\
\hline Austria & 462 & 1491 \\
\hline Belgia & 579 & 1869 \\
\hline Bułgaria & 201 & 651 \\
\hline Chorwacja & 134 & 434 \\
\hline Cypr & 35 & 112 \\
\hline Estonia & 47 & 152 \\
\hline Finlandia & 304 & 982 \\
\hline Francja & 3064 & 9898 \\
\hline Hiszpania & 1896 & 6127 \\
\hline Litwa & 98 & 318 \\
\hline Luksemburg & 56 & 181 \\
\hline Lotwa & 66 & 215 \\
\hline Malta & 17 & 54 \\
\hline Holandia & 922 & 2978 \\
\hline Niemcy & 4027 & 13009 \\
\hline Polska & 1201 & 3881 \\
\hline Portugalia & 388 & 1254 \\
\hline Republika Czech & 376 & 1215 \\
\hline Rumunia & 585 & 1890 \\
\hline Słowacja & 190 & 612 \\
\hline Słowenia & 80 & 257 \\
\hline Szwecja & 567 & 1830 \\
\hline Węgry & 306 & 988 \\
\hline
\end{tabular}

Źródło: Opracowanie własne na podstawie Załacznik do Decyzji Rady (UE) 2015/1601 z dnia 22 września 2015 roku ustanawiajaca środki tymczasowe w obszarze ochrony międzynarodowej na rzecz Włoch $i$ Grecji, Dz. U. UE L 2015.248.80.

W sumie relokacji miało być poddane 160000 osób. Była to suma transferu 40000 osób zaakceptowana przez Parlament Europejski w dniu 9 września i przyjęta przez Radę ds. Wymiaru Sprawiedliwości i Spraw Wewnętrznych w dniu 14 września oraz 120000 osób zgodna z decyzją Rady UE z dnia 22 września 2015 roku.

Pierwsza relokacja w ramach UE miała miejsce 9 października 2015 roku. W tym dniu z Rzymu do Szwecji udało się 19 osób pochodzących z Erytrei. W tym samym miesiącu wykonano jeszcze jeden transfer do Szwecji (19 Syryjczyków) i Finlandii (49 obywateli Erytrei). W listopadzie na relokację zgodziła się Francja (19 Erytrejczyków), Hiszpania (11 obywateli Erytrei i 1 Syrii) i Szwecja (1 kobieta z Erytrei). Z kolei w ostatnim miesiącu 2015 roku z Włoch relokowano uchodźców do: Finlandii (38 osób), Portugalii (10 osób), Belgii (6 osób) oraz Hiszpanii (6 osób - Annex, 2016a, s. 5). Łącznie wg danych na dzień 11 lutego 2016 roku relokacji uchodźców z Włoch podjęło się 7 państw. Wśród nich były: Szwecja (39 osób), Belgia (14 osób), Finlandia (96 osób), Francja (41 osób), Holandia (50 osób), Niemcy (11 osób), Portugalia (10 osób) i Hiszpania (18 osób - Member States, 2016).

Z Grecji relokację rozpoczęto 4 listopada 2015 roku. Pierwszych 30 osób (z Syrii i Iraku) przetransportowano do Luksemburga. W grudniu z kolei relokowano uchodźców na Litwę (czteroosobowa irańska rodzina), do Finlandii (24 osoby z Erytrei), Niemiec (10 osób z Iraku i Syrii) i Portugalii (12 obywateli Iraku i 2 Syrii - Annex, 2016a, s. 3). 
Łącznie wg danych z 11 lutego 2016 roku z Grecji przewieziono imigrantów do: Luksemburga (30 osób), Litwy (4 osoby), Finlandii (44 osoby), Niemiec (31 osób), Francji (94 osoby), Portugalii (20 osób), Irlandii (10 osób), Łotwy (6 osób) i na Cypr (6 osób - Member States, 2016).

W sumie, do 11 lutego 2016 roku, relokowano 524 osoby, w tym 279 z Włoch (spośród 39 600) i 245 osób z Grecji (z 66400 - Member States, 2016). Stan ten w stosunku do stycznia znacznie się poprawił, bowiem wzrósł o 252 osoby (Relocation 2016, Member States, 2016). Dotyczyło to także kolejnego miesiąca, w którym łączna liczba relokowanych imigrantów wyniosła 937 osób, co oznaczało zwiększenie ich liczby o 413 (dane z 15 marca 2016 roku, Umverteilung, 2016). Zdecydowany przyrost relokowanych widoczny był z Grecji (o 324 osoby). Do państw, które wzięły udział w relokacji dołączyły: Bułgaria, Malta i Rumunia (od 11 lutego do 15 marca).

Tabela 5

\section{Relokacja uchodźców z Wloch i Grecji do poszczególnych państw wg stanu na dzień 15 marca 2016 roku}

\begin{tabular}{|l|c|c|c|c|}
\hline \multicolumn{1}{|c|}{ Państwo } & $\begin{array}{c}\text { Formalnie } \\
\text { zadeklarowane }\end{array}$ & $\begin{array}{c}\text { Relokacja } \\
\text { z Wloch }\end{array}$ & $\begin{array}{c}\text { Relokacja } \\
\text { z Grecji }\end{array}$ & $\begin{array}{c}\text { Liczba osób } \\
\text { do relokacji }\end{array}$ \\
\hline Belgia & 30 & 24 & 0 & 3812 \\
\hline Bułgaria & 250 & 0 & 2 & 1302 \\
\hline Cypr & 80 & 0 & 6 & 320 \\
\hline Czechy & 30 & 0 & 0 & 2691 \\
\hline Estonia & 31 & 0 & 0 & 329 \\
\hline Finlandia & 320 & 96 & 77 & 2078 \\
\hline Francja & 770 & 41 & 242 & 19714 \\
\hline Niemcy & 50 & 20 & 37 & 27536 \\
\hline Irlandia & 60 & 0 & 10 & 600 \\
\hline Lotwa & 46 & 0 & 6 & 481 \\
\hline Litwa & 80 & 0 & 6 & 671 \\
\hline Luksemburg & 100 & 0 & 30 & 557 \\
\hline Malta & 23 & 15 & 6 & 131 \\
\hline Holandia & 200 & 50 & 48 & 5947 \\
\hline Polska & 100 & 0 & 0 & 6182 \\
\hline Portugalia & 718 & 65 & 84 & 2951 \\
\hline Rumunia & 515 & 0 & 15 & 4180 \\
\hline Hiszpania & 200 & 18 & 0 & 9323 \\
\hline Słowenia & 40 & 0 & 0 & 467 \\
\hline Szwecja & 50 & 39 & 0 & 3766 \\
\hline Szwajcaria & 30 & 0 & 0 & b.d. \\
\hline Razem & 3723 & 368 & 569 & 93038 \\
\hline
\end{tabular}

Źródło: Opracowanie własne na podstawie: Annex to the Communication from the Commission to the European Parlament, the European Council and the Council. First report on relocation and resettlement, Annex 1 (2016c), European Commission, Brussels 16.03.2016, http:/ec.europa.eu/dgs/home-affairs/what-we-do/policies/european-agenda-migration/proposal-implementation-package/docs/20160316/first_report_on_relocation_and_resettlement_-_annex_1_en.pdf, 18.03.2016; Annex to the Communication from the Commission to the European Parlament, the European Council and the Council. First report on relocation and resettlement, Annex 2 (2016d), European Commission, Brussels 16.03.2016, http://ec.europa.eu/dgs/home-affairs/ what-we-do/policies/european-agenda-migration/proposal-implementation-package/docs/20160316/first_report_on_relocation_and_resettlement_-_annex_2_en.pdf, 18.03.2016. 
W dzienniku „Corriere della Sera” pod koniec października 2015 roku napisano, iż plan relokacji imigrantów to porażka (Corriere, 2015). Szef włoskiego departamentu ds. migracji Mario Morcone wskazał na trzy przyczyny fiaska tego procesu. Wśród nich były: skomplikowana procedura relokacji imigrantów, ograniczenie do kilku narodowości osób podlegających tej procedurze (Irak, Syria, Erytrea) oraz niechęć państw do ich przyjmowania (Włosi, 2016). Do innych przyczyn można było zaliczyć także awersję samych imigrantów do rejestrowania się w pierwszym państwie, do którego dotrą (Włoch i Grecji), co było warunkiem objęcia relokacją. Cudzoziemcy tego najczęściej nie czynili, ponieważ chcieli się dostać do Niemiec czy Szwecji, a nie do Polski czy Rumunii (Bielecki, 2016). Ponadto rządy Grecji i Włoch nie uruchomiły zaplanowanej liczby 11 centrów rejestracji uchodźców (hotspots) tylko 3 (w tym 2 we Włoszech na Lampedusie i w Pozzallo oraz 1 na wyspie Lesbos w Grecji - ibidem). Prace nad uruchomieniem kolejnych trwają.

W listopadzie węgierski parlament upoważnił rząd do złożenia skargi do Europejskiego Trybunału Sprawiedliwości. Dotyczyła ona decyzji Komisji Europejskiej w sprawie obowiązkowego rozmieszczenia uchodźców w poszczególnych państwach członkowskich UE. Swój brak akceptacji do poczynań UE w tym zakresie wyraziły także władze Bułgarii, które wcześniej zgodziły się na unijny plan w zakresie migracji. W gronie tym znalazła się ponadto Słowacja, domagając się unieważnienia przez trybunał zasądzonych we wrześniu kwot imigrantów objętych relokacją. Premier tego państwa Robert Fico oznajmił, że Słowacja nie będzie respektować tej decyzji dopóki będzie szefem rządu (Reakcja, 2015). Czeski rząd nie przyłączył się do słowackiego pozwu. W listopadzie duński premier Lars Lokke Rasmussen poinformował o odmowie przyjęcia w ramach relokacji 1000 uchodźców. Wśród przeciwników systemu kwotowego była również Polska, ale ostatecznie władze zgodziły się na wzięcie udziału w programie relokacji. Nowy rząd PiS mimo, iż uznał wcześniejsze ustalenia, to jednak oponował wobec dodatkowym kwotom, podobnie jak Francja. Z systemu relokacji wyłączone były Wielka Brytania i Dania (na podstawie art. 1 i 2 protokołu 22 dołączonego do Traktatu o funkcjonowaniu UE).

W grudniu 2015 roku Komisja Europejska przyjęła wniosek Szwecji w sprawie wyłączenia jej z programu relokacji uchodźców z terenów Grecji i Włoch na co najmniej rok. Powodem był fakt, że do Szwecji przybyła rekordowa liczba imigrantów z Bliskiego Wschodu. Jednocześnie, Szwedzi złożyli w Komisji Europejskiej wniosek o przesiedlenie uchodźców z ich kraju na terytoria innych państw UE. Tymczasowym zawieszeniem relokacji objęto także Austrię (Decyzja wykonawcza, 2016). Na podstawie art. 1 decyzji z dnia 8 marca 2016 roku odroczono relokację 1065 imigrantów z Włoch i Grecji (dotyczy to 30\% wnioskodawców przydzielonych Austrii na mocy decyzji UE 2015/1601 przez okres 1 roku). Powodem tego stanowiska był gwałtowny wzrost wnioskodawców ubiegających się o ochronę międzynarodową na terenie Austrii.

Wraz z relokacją rozpoczęto także przesiedlenia. Na podstawie programu uzgodnionego w dniu 20 lipca 2015 roku przetransferowano na teren UE 4555 cudzoziemców, wg danych na dzień 15 marca 2016 roku (Umverteilung, 2016). Wśród osób przesiedlonych znaleźli się obywatele: Libanu, Jordanii, Turcji, Iraku, Syrii, Maroko, Etiopii i Egiptu (Annex, 2016e). 
Liczba przesiedlonych spoza UE do poszczególnych państw wg danych na dzień 15 marca 2016 roku

\begin{tabular}{|c|c|c|}
\hline $\begin{array}{l}\text { Państwo przyjmujące } \\
\text { przesiedleńców }\end{array}$ & Liczba osób przesiedlonych & $\begin{array}{c}\text { Ogólna liczba zaakceptowana } \\
\text { do przesiedleń } 20.07 .2015 \text { r. }\end{array}$ \\
\hline Austria & 1395 & 1900 \\
\hline Belgia & 212 & 1100 \\
\hline Bułgaria & 0 & 50 \\
\hline Chorwacja & 0 & 150 \\
\hline Cypr & 0 & 69 \\
\hline Czechy & 52 & 400 \\
\hline Dania & b.d. & 1000 \\
\hline Estonia & 0 & 20 \\
\hline Finlandia & 0 & 293 \\
\hline Francja & 15 & 2375 \\
\hline Grecja & 0 & 354 \\
\hline Hiszpania & 0 & 1449 \\
\hline Holandia & 231 & 1000 \\
\hline Islandia & b.d. & 50 \\
\hline Irlandia & 251 & 520 \\
\hline Lichtenstein & 20 & 20 \\
\hline Litwa & 0 & 70 \\
\hline Luksemburg & 0 & 30 \\
\hline Łotwa & 0 & 50 \\
\hline Malta & 0 & 14 \\
\hline Niemcy & 0 & 1600 \\
\hline Norwegia & 6 & 3500 \\
\hline Polska & 0 & 900 \\
\hline Portugalia & 0 & 191 \\
\hline Rumunia & 0 & 80 \\
\hline Słowacja & 0 & 100 \\
\hline Słowenia & 0 & 20 \\
\hline Szwecja & 0 & 491 \\
\hline Węgry & 0 & 0 \\
\hline Włochy & 96 & 1989 \\
\hline Wielka Brytania & 1864 & 2200 \\
\hline Szwajcaria & 413 & 519 \\
\hline Razem & 4555 & 22504 \\
\hline
\end{tabular}

Źródło: Annex to the Communication from the Commission to the European Parlament, the European Council and the Council. First report on relocation and resettlement, Annex 6 (2016e), European Commission, Brussels 16.03.2016, http://ec.europa.eu/dgs/home-affairs/what-we-do/policies/european-agenda-migration/ proposal-implementation-package/docs/20160316/first_report_on_relocation_and_resettlement_-_annex_2_ en.pdf, 18.03.2016.

Kolejnym sposobem złagodzenia kryzysu imigranckiego w UE było przygotowanie planu powrotów nielegalnych imigrantów (zapowiedzianego w 10-punktowym planie z dnia 20 kwietnia 2015 roku). Przyjęto go we wrześniu 2015 roku (Plan działania, 2015). Jego celem miało być między inny zwiększenie skuteczności powrotów nielegalnych imigrantów i zacieśnienie współpracy operacyjnej między państwami członkowskimi, agencjami UE i państwami pochodzenia cudzoziemców (ibidem, s. 2). Realizacja 
tego planu uwzględniała międzynarodowe standardy w zakresie ochrony praw człowieka oraz dyrektywę Parlamentu Europejskiego i Rady z 16 grudnia 2008 roku (Dyrektywa, 2008). Środki na realizację zadań w tym zakresie pochodziły z Funduszu Azylu, Migracji i Integracji. Postanowiono przeznaczyć na nie ponad $800 \mathrm{mln}$ euro w latach 2014-2020 (Plan działania, 2015, s. 3). W celu zwiększenia skuteczności powrotów zaproponowano:

- wzrost liczby osób podlegających powrotom dobrowolnym i przymusowym;

- skuteczne egzekwowanie prawa unijnego w zakresie powrotów;

- położenie nacisku na wymianę informacji między państwami na temat wydanych przez siebie decyzji nakazujących cudzoziemcom powrót lub zakazujących wjazdu;

- zwiększenie roli Frontexu w zakresie powrotu imigrantów;

- opracowanie zintegrowanego systemu zarządzania powrotami;

- rozwijanie współpracy w zakresie readmisji z krajami pochodzenia i tranzytu nielegalnych imigrantów (ibidem, s. 3-17).

Z analizy statystyk jawi się jednak znaczna różnica między liczbą osób, którym wydano decyzję nakazującą powrót, a liczbą osób, które w następstwie tej decyzji wyjechały z terenu UE. Wg danych z 2014 roku uczyniło to jedynie 36\% osób zakwalifikowanych do powrotu. Łącznie 470080 obywateli państw trzecich otrzymało nakaz powrotu. $67 \%$ z tej liczby przypadło na cztery państwa - Francję (86 955 imigrantów), Grecję (73 670), Wielką Brytanię (65 365) i Hiszpanię (42 150 - Third country, 2015; EMN Annual, 2015, s. 84). W omawianym okresie wyjechało jedynie 168925 cudzoziemców, z czego 46610 z Wielkiej Brytanii, 27055 z Grecji, 19525 z Francji i 15150 osób z Hiszpanii (ibidem). Wśród nich najwięcej było obywateli Syrii (44 470), Maroka (32 825) i Albanii (29 665 - Number, 2015).

Rozwiązaniu problemu napływu imigrantów o nieuregulowanym statusie do UE służyła również współpraca z innymi państwami. Dotyczyło to krajów pochodzenia imigrantów, jak i tranzytu. W ramach tego zadania państwa członkowskie UE podjęły kooperację między innymi z państwami afrykańskimi, Turcją oraz krajami Bałkanów Zachodnich.

Potrzebę zorganizowania spotkania z państwami afrykańskimi zgłosili uczestnicy nadzwyczajnego szczytu Rady Europejskiej w dniu 23 kwietnia 2015 roku. Następnie europejscy i afrykańscy przywódcy podjęli temat migracji podczas szczytu w Valletcie w listopadzie 2015 roku. Uznano go wówczas za wspólny problem. Przyjęto deklarację i 16-punktowy plan działań, który ma być zrealizowany do końca 2016 roku. Efektem spotkania było również uruchomienie nadzwyczajnego funduszu powierniczego na rzecz stabilizacji oraz eliminacji przyczyn migracji nieuregulowanej i przesiedleń w Afryce. Z budżetu UE i Europejskiego Funduszu Rozwoju wyasygnowano na ten cel 1,8 mld euro. Ponadto swoje deklaracje finansowe złożyły państwa członkowskie ( $A E u$ ropean, 2015). Podczas szczytu na Malcie UE i Etiopia podpisały wspólny program w obszarze migracji i mobilności.

O potrzebie podjęcia współpracy z Turcją w zakresie migracji rozmawiano wielokrotnie. Dotyczyło to na przykład: nieformalnego szczytu szefów państw i rządów w dniu 23 września 2015 roku, konferencji wysokiego szczebla w sprawie szlaku wschodniośródziemnomorskiego i zachodniobałkańskiego w Luksemburgu w dniu 8 października 2015 roku, posiedzeniu Rady Europejskiej w dniu 15 października 2015 roku, nieformalnego szczytu szefów państw i rządów w Valettcie w dniu 12 listopada 2015 roku oraz szczytu UE-Turcja 
w dniu 29 listopada 2015 roku. Podczas ostatniego z wymienionych spotkań UE zapewniła Turcję o swojej pomocy finansowej w ramach uruchomionego Instrumentu Pomocy dla Uchodźców w Turcji od dnia 1 stycznia 2016 roku (na łączną kwotę 3 mld euro, w tym 1 mld euro z budżetu UE, a 2 mld euro ze składek członkowskich, Decyzja, 24.11.2015). Strony wprowadziły także w życie postanowienia planu działań w zakresie migracji (przyjęty 15 października na posiedzeniu Rady Europejskiej), jak i zapowiedziały realizację umowy o readmisji z czerwca 2016 roku (EU-Turkey, 2015). W celu udzielenia pomocy finansowej dla Turcji państwa członkowskie, w dniu 3 lutego 2016 roku, uzgodniły rozkład składek między poszczególne państwa członkowskie (2 mln euro). Najwięcej środków ma pochodzić z Niemiec (427,5 mln euro), Wielkiej Brytanii (327,6 mln euro) i Francji $(309,2 \mathrm{mln}$ euro). Polska na fundusz wyłoży $57 \mathrm{mln}$ euro (Instrument, 2016). W dniu 10 lutego 2016 roku Komisja Europejska uaktualniła priorytety w ramach Instrumentu Pomocy dla Uchodźców w Turcji (Annex, 2016a). Do kolejnego szczytu UE-Turcja doszło 7 marca 2016 roku. Uzgodniono wówczas wiele działań w zakresie migracji, wśród których były między innymi: odsyłanie wszystkich nowych imigrantów o nieuregulowanym statusie przedostających się z Turcji do Grecji na koszt UE, przyspieszenie wypłaty przydzielonych wcześniej 3 mld euro oraz współdziałanie z Turcją na rzecz poprawy warunków humanitarnych w obrębie Syrii (Oświadczenie, 2016a). Współpracę kontynuowano także na spotkaniu w dniu 18 marca 2016 roku. Uzgodniono wówczas dziewięć działań mających na celu położenie kresu nieuregulowanej imigracji z Turcji do państw członkowskich UE (Oświadczenie, 2016b).

Poza Turcją UE zdecydowała także o wsparciu państw Bałkanów Zachodnich w zakresie radzenia sobie z niekontrolowanym przepływem cudzoziemców. Problematyka ta było przedmiotem rozmów szefów państw i rządów w dniu 23 września 2015 roku. Następnie dyskutowano o tym podczas konferencji w sprawie wschodniośródziemnomorskiego i zachodniobałkańskiego szlaku, która odbyła się w Luksemburgu w dniu 8 października 2015 roku. Przyjęto na niej deklarację, w której między innymi zobowiązano partnerów do większej solidarności i sprawniejszego zarządzania przepływami imigrantów (High, 2015).

W związku z tym, iż przez Bałkany przebiegał szlak najczęściej wybierany przez imigrantów Komisja Europejska zorganizowała w Brukseli, w dniu 25 października, spotkanie przywódców jedenastu państw (Albanii, Austrii, Bułgarii, Chorwacji, Grecji, Macedonii, Niemiec, Rumunii, Serbii, Słowenii i Węgier). Na spotkaniu przyjęto 17-punktowy plan działania oparty na solidarności i odpowiedzialności. Jego celem było przywrócenie stabilności w zarządzaniu migracjami w regionie szlaku zachodniobałkańskiego (Leaders' Meeting, 2015). Wśród postanowień znalazło się między innymi:

- wyznaczenie punktów kontaktowych (ułatwiających wymianę informacji i koordynację działań);

- udzielenie pomocy humanitarnej imigrantom udającym się szlakiem bałkańskim do UE (tymczasowego schronienia, jedzenia);

- zapewnienie szybkiej z pełnym poszanowaniem godności i praw człowieka organizacji powrotów cudzoziemcom niepotrzebujących ochrony międzynarodowej. W tym celu postanowiono zintensyfikować współpracę w ramach readmisji szczególnie z Afganistanem, Bangladeszem i Pakistanem oraz przygotować umowy readmisyjne $\mathrm{z}$ innymi państwami, z którymi nie zawarto stosownych porozumień $\mathrm{w}$ tym zakresie; 
- zwiększenie wysiłków na rzecz odzyskania kontroli na granicach UE i lepszej koordynacji działań w zakresie zarządzania granicami zewnętrznymi;

- wsparcie ze strony Frontex ochrony granic Grecji, między Bułgarią a Turcją oraz chorwacko-serbskiej;

- wysłanie 400 funkcjonariuszy, w ciagu tygodnia, do Słowenii w celu kontroli granic;

- wzmocnienie współpracy transgranicznej między Grecją a Byłą Jugosłowiańską Republiką Macedonii;

- zapewnienie przez Grecję, do końca 2015 roku, 30000 miejsc dla imigrantów;

- utworzenie dla 50000 osób ośrodków wzdłuż szlaku migracyjnego przy wsparciu Biura Wysokiego Komisarza ONZ ds. Uchodźców;

- wzmocnienie współpracy policyjnej i sądowej oraz zintensyfikowanie działań przeciwko handlowi ludźmi (ibidem).

O ważności pomocy dla państw z rejonu Bałkanów Zachodnich świadczył fakt, iż na mocy decyzji Komisji Europejskiej z dnia 21 grudnia 2015 roku działania w tym regionie wsparto środkami z regionalnego funduszu powierniczego Madad (Commission Decision of 21.12.2015).

Uzupełnieniem powyższych działań było uruchomienie dla Syrii funduszów na pomoc humanitarna, gospodarczą i stabilizacyjną oraz państw sąsiadujących, które przyjęły ich obywateli (Libanu, Jordanii, Iraku, Egiptu, Turcji). Środki finansowe na ww. cele pochodziły z Europejskiego Instrumentu Sąsiedztwa, Instrumentu na rzecz Przyczyniania się do Stabilności i Pokoju, Instrumentu Finansowania Współpracy na rzecz Rozwoju na lata 2014-2020, regionalnego programu rozwoju i ochrony oraz regionalnego funduszu powierniczego UE w odpowiedzi na syryjski kryzys „Fundusz Madad”. Ostatni z nich ustanowiony został w grudniu 2014 roku. Objął on swoim zasięgiem Syrię, Liban, Jordanię, Irak, Egipt, Turcję i inne państwa w regionie dotknięte przez kryzys syryjski (art. 1 pkt 5, Commission Decision of 10.12.2014). W dniu 23 września 2015 roku na nieformalnym posiedzeniu szefów państw i rządów podjęto decyzję o uruchomieniu dodatkowych środków na ten fundusz. Kwestia ta była również przedmiotem rozmów podczas międzynarodowej konferencji zatytułowanej „Wspierając Syrię i region” w Londynie, która odbyła się w lutym 2016 roku. Wówczas postanowiono przeznaczyć w 2016 roku ponad 3 mld euro na pomoc Syryjczykom w Syrii, syryjskim uchodźcom i społeczności ich przyjmujących w państwach ościennych (Po konferencji, 2016). Premier RP Beata Szydło zdecydowała o przekazaniu 4,5 mln euro, z czego $3 \mathrm{mln}$ euro na pomoc humanitarną w Syrii, a 1,5 mln euro na uchodźców w państwach sąsiadujących (Beata Szydto, 2016).

Tabela 6

Zestawienie środków finansowych państw czlonkowskich, Norwegii i Szwajcarii na fundusz powierniczy na rzecz stabilizacji oraz eliminacji przyczyn migracji nieuregulowanej i przesiedleń w Afryce oraz regionalny fundusz powierniczy UE w odpowiedzi na syryjski kryzys „Fundusz Madad” w milionach euro na dzień 11 lutego 2016 roku

\begin{tabular}{|l|c|c|c||}
\hline \multicolumn{1}{|c|}{ Państwo } & $\begin{array}{c}\text { Fundusz na rzecz } \\
\text { Afryki }\end{array}$ & Fundusz Madad & Razem \\
\hline \multicolumn{1}{|c|}{1} & 2 & 3 & 4 \\
\hline Austria & 3 & 11,5 & 14,5 \\
\hline Belgia & 10 & - & 10 \\
\hline Bułgaria & 0,05 & 0,1 & 0,15 \\
\hline
\end{tabular}




\begin{tabular}{|c|c|c|c|}
\hline 1 & 2 & 3 & 4 \\
\hline Chorwacja & - & - & - \\
\hline Cypr & - & - & - \\
\hline Czechy & 0,74 & 5 & 5,74 \\
\hline Dania & 6 & 9,75 & 15,75 \\
\hline Estonia & 0,15 & 0,25 & 0,40 \\
\hline Finlandia & 5 & 3 & 8 \\
\hline Francja & 3 & 3 & 6 \\
\hline Niemcy & 3 & 5 & 8 \\
\hline Grecja & - & - & - \\
\hline Węgry & 0,7 & 3 & 3,7 \\
\hline Irlandia & 3 & - & 3 \\
\hline Włochy & 10 & 5 & 15 \\
\hline Łotwa & 0,05 & 0,05 & 0,1 \\
\hline Litwa & 0,05 & 0,1 & 0,15 \\
\hline Luksemburg & 3,1 & - & 3,1 \\
\hline Malta & 0,25 & 0,02 & 0,27 \\
\hline Holandia & 15 & 5 & 20 \\
\hline Polska & 1,1 & 3 & 1,4 \\
\hline Portugalia & 0,25 & 0,2 & 0,45 \\
\hline Rumunia & 0,1 & 0,08 & 0,18 \\
\hline Słowacja & 0,5 & 3 & 3,5 \\
\hline Słowenia & 0,05 & - & 0,05 \\
\hline Hiszpania & 3 & - & 3 \\
\hline Szwecja & 3 & 3 & 6 \\
\hline Wielka Brytania & 3 & - & 3 \\
\hline Norwegia & 3 & - & 3 \\
\hline Szwajcaria & 4,62 & - & 4,62 \\
\hline razem & 81,71 & 60,05 & 141,76 \\
\hline Wkład UE & 1800 & 500 & 2300 \\
\hline
\end{tabular}

Źródło: Annex to the Communication from the Commission to the European Parliament and the Council on the State of Play of Implementation of the Priority Actions under the European Agenda on Migration Member States' pledging to Trust Funds - State of Play table, European Cmmission (2016b), Brussels, 10.02.2016. s. 2, http://ec.europa.eu/dgs/home-affairs/what-we-do/policies/european-agenda-migration/ proposal-implementation-package/docs/managing_the_refugee_crisis_state_of_play_20160210_annex_07_ en.pdf, 1.03.2016.

Podsumowując powyższe rozważania należy stwierdzić, iż na obecny kryzys imigracyjny wpływ wywarły bezpośrednio konflikty zbrojne, w tym w Syrii. Wśród innych powodów było także: ubóstwo, łamanie praw człowieka, zmiany klimatyczne, trendy demograficzne oraz postępująca globalizacja w zakresie komunikacji i transportu. Napływ imigrantów do UE w 2015 roku był rekordowy. Pierwszy kwartał 2016 roku pokazał, że tendencja w tym zakresie nie słabnie. Sytuacja ta stawia przed UE zadanie wzmocnienia unijnego systemu migracyjnego. Wymaga także większej solidarności europejskiej, szczególnie w zakresie radzenia sobie ze skutkami nielegalnej imigracji.

Jak wykazano w niniejszym artykule, wiele wysiłku na poziomie UE włożono już w działania na rzecz rozwiązywania problemu imigracyjnego (relokacja, przesiedlenia, powroty, readmisja, dodatkowe środki finansowe z budżetu UE na kryzys imigracyjny, zacieśnienie współpracy z państwami Afryki, Bałkanów Zachodnich, Turcji). Nie udało się jednak powstrzymać fali uchodźców. Reakcje społeczeństw państw członkowskich 
UE były coraz częściej negatywne. Nasilały się demonstracje antyimigranckie. Pojawiały się także deklaracje polityków i konkretne działania władz państwowych zmierzające do ograniczenia napływu imigrantów (np. zmiany w prawie azylowym, limity przyjmowania uchodźców). Próby rozwiązania kryzysu imigracyjnego ujawniły brak solidarności szczególnie ze strony państw Europy Środkowej i Wschodniej. Dotyczyło to przede wszystkich ich udziału w programie relokacji imigrantów z Grecji i Włoch.

Kryzys imigracyjny stawia przed UE i jej instytucjami wiele zdań. Do nich należą działania mające na celu wzmocnienie wewnętrznej jedności, realizację już podjętych decyzji, zmniejszenie liczby napływających do UE cudzoziemców oraz uszczelnienie zewnętrznych granic UE.

\section{Bibliografia}

Aktuelle Zahlen zu Asyl, Budesamt für Migration und Flüchtlinge (2016), https://www.bamf.de/SharedDocs/Anlagen/DE/Downloads/Infothek/Statistik/Asyl/statistik-anlage-teil-4-aktuelle-zahlenzu-asyl.pdf?_blob=publicationFile, 1.03.2016.

Annex to the Communication from the Commission to the European Parliament and the Council on the State of Play of Implementation of the Priority Actions under the European Agenda on Migration EU-Turkey Joint Annex to the Communication from the Commission to the European Parliament and the Council on the State of Play of Implementation of the Priority Actions under the European Agenda on Migration Relocation - State of Play Table, European Commission, Brussels (2016a), http://ec.europa.eu/dgs/home-affairs/what-we-do/policies/european-agendamigration/proposal-implementation-package/docs/managing_the_refugee_crisis_state_of_ play_20160210_annex_04_en.pdf, 1.03.2016.

Annex to the Communication from the Commission to the European Parliament and the Council on the State of Play of Implementation of the Priority Actions under the European Agenda on Migration Member States 'pledging to Trust Funds - State of Play table, European Cmmission, Brussels (2016b), http://ec.europa.eu/dgs/home-affairs/what-we-do/policies/european-agendamigration/proposal-implementation-package/docs/managing_the_refugee_crisis_state_of_ play_20160210_annex_07_en.pdf, 1.03.2016.

Annex to the Communication from the Commission to the European Parlament, the European Council and the Council. First report on relocation and resettlement, Annex 1, European Commission, Brussels (2016c), http://ec.europa.eu/dgs/home-affairs/what-we-do/policies/european-agendamigration/proposal-implementation-package/docs/20160316/first_report_on_relocation_and_ resettlement_-_annex_1_en.pdf, 18.03.2016.

Annex to the Communication from the Commission to the European Parlament, the European Council and the Council. First report on relocation and resettlement, Annex 2, European Commission, Brussels (2016d), http://ec.europa.eu/dgs/home-affairs/what-we-do/policies/european-agendamigration/proposal-implementation-package/docs/20160316/first_report_on_relocation_and_ resettlement_-_annex_2_en.pdf, 18.03.2016.

Annex to the Communication from the Commission to the European Parlament, the European Council and the Council. First report on relocation and resettlement, Annex 6, European Commission, Brussels (2016e), http://ec.europa.eu/dgs/home-affairs/what-we-do/policies/european-agendamigration/proposal-implementation-package/docs/20160316/first_report_on_relocation_and_ resettlement_-_annex_6_en.pdf, 18.03.2016.

Asylgeschäftsstatistik für den Monat Dezember 2015, Budesamt für Migration und Flüchtlinge (2015), https:/www.bamf.de/SharedDocs/Anlagen/DE/Downloads/Infothek/Statistik/Asyl/201512-statistik-anlage-asyl-geschaeftsbericht.pdf?_blob=publicationFile, 1.03.2016. 
Asylum and new asylum applicants - annual aggregated data (2016a), Eurostat, http://ec.europa.eu/eurostat $/$ tgm/table.do?tab=table\&init=1\&plugin=1\&pcode=tps00191\&language=en, 17.02.2016.

Asylum and first time applicants by citizenship, age and sex Monthly data (2016b), Eurostat, http:// appsso.eurostat.ec.europa.eu/nui/show.do, 17.02.2016.

Asylum in the EU Member States Record number of o ver 1.2 million first time asylum seekers registered in 2015. Syrians, Afghans and Iraqis: top citizenship, Eurostat Newesrelease (2016c), 44/2016, Eurostat, http://ec.europa.eu/eurostat/documents/2995521/7203832/3-04032016-APEN.pdf/790eba01-381c-4163-bcd2-a54959b99ed6, 18.03.2016.

A European Agend on Migration, Summit on Migration (2015), Valletta, http://www.consilium.europa. $\mathrm{eu} / \mathrm{pl} / \mathrm{meetings/international-summit/2015/11/11-12/,} \mathrm{7.02.2016.}$

Beata Szydło: Polska przeznaczy 4,5 mln euro na kryzys humanitarny (2016), http://www.rmf24.pl/ raporty/raport-fala-uchodzcow/najnowsze-fakty/news-beata-szydlo-polska-przeznaczy-4-5mln-euro-na-kryzys-humani,nId,2140256, 1.03.2016.

Bielecki J., Największa porażka Europy (2016), http://www.rp.pl/Uchodzcy/301109931-Najwiekszaporazka-Europy.html\#ap-1, 3.03.2016.

Commission Decision of 10.12.2014 on the establishment of a European Union Regional Trust Fund in response to the Syrian crisis, ,the Madad Fund” (2014), http://ec.europa.eu/enlargement/ neighbourhood/pdf/key-documents/syria_2014_9615_f1_comission_decision793137.pdf, 1.02.2016.

Commission Decision of 21.12.2015 amending Decision C(2014) 9615 final on the establishment of a European Union Regional Trust Fund in response to the Syrian crisis, ,the Madad Fund” (2015), http://ec.europa.eu/enlargement/neighbourhood/pdf/key-documents/syria/2015-modeu-trust-fund-syrian-crisis-establishment-commission-decision.pdf, 1.03.2016.

Coraz więcej ataków na ośrodki dla uchodźców w Niemczech (2016), http://www.tvn24.pl/wiadomosci-ze-swiata,2/niemcy-wzrasta-liczba-atakow-na-osrodki-dla-imigrantow,614562.html, 2.03.2016.

„Corriere della Sera”: fiasko planu relokacji migrantów (2015), http://www.bankier.pl/wiadomosc/ Corriere-della-Sera-fiasko-planu-relokacji-migrantow-3431371.html, 20.02.2016.

Decyzja nr 573/2007/WE Parlamentu Europejskiego i Rady z dnia 23 maja 2007 roku ustanawiajaca Europejski Fundusz na rzecz uchodźców na lata 2008-2013 jako część programu ogólnego „Solidarność i zarzadzanie przeptywami migracyjnymi” oraz uchylajaca decyzje Rady 2004/904/WE, Dz. U. UE L 2007.144.1.

Decyzja Rady (UE) 2015/1523 z dnia 14 września 2015 roku ustanawiajaca środki tymczasowe w obszarze ochrony międzynarodowej na rzecz Włoch i Grecji, Dz. U. UE L 2015.239.146.

Decyzja Rady (UE) 2015/1601 z dnia 22 września 2015 roku ustanawiajaca środki tymczasowe w obszarze ochrony międzynarodowej na rzecz Włoch i Grecji, Dz. U. UE L 2015.248.80.

Decyzja Rady wprowadzająca środki tymczasowe $w$ dziedzinie ochrony międzynarodowej na rzecz Włoch, Grecji i Wegier (2015), Bruksela 9.09.2015 r., https://ec.europa.eu/transparency/regdoc/rep/1/2015/PL/1-2015-451-PL-F1-1.PDF, 1.03.2016.

Decyzja wykonawcza Rady w sprawie tymczasowego zawieszenia relokacji 30\% wnioskodawców przydzielonych Austrii na mocy decyzji (UE) 2015/1601 ustanawiajacej środki tymczasowe w obszarze ochrony międzynarodowej na rzecz Włoch i Grecji (2016), Bruksela, 8 marca 2016 r., http://data.consilium.europa.eu/doc/document/ST-6715-2016-INIT/pl/pdf, 11.03.2016.

Decyzja z dnia 24 listopada 2015 roku w sprawie koordynacji działań Unii i państw członkowskich przy użyciu mechanizmu koordynacji - Instrumentu Pomocy dla Uchodźców w Turcji, Dz. U. UE C 2015.407.8.

Dyrektywa Parlamentu Europejskiego i Rady 2008/115/WE z dnia 16 grudnia 2008 roku w sprawie wspólnych norm i procedur stosowanych przez państwa członkowskie w odniesieniu do powrotów nielegalnie przebywajacych obywateli państw trzecich, Dz. U. UE L 2008.348.98. 
EASO Fast findeing report on intra-EU relocation activities from Malta (2012), https://easo.europa.eu/ wp-content/uploads/EUREMA-fact-finding-report-EASO1.pdf, 12.03.2016.

EMN Annual Report on Immigration and Asylum 2014 A Synthesis of Annual Policy Reports 2014 submitted by EU Member States and Norway, European Migration Network (2015), http:// ec.europa.eu/dgs/home-affairs/what-we-do/networks/european_migration_network/reports/ docs/annual-policy/2014/00.emn_annual_report_on_immigration_and_asylum_synthesis_report.pdf, 5.03.2016.

EUREMA II: Polska niesie ulgę Malcie (2013), http://biuletynmigracyjny.uw.edu.pl/40-luty-2013/eurema-ii-polska-niesie-ulge-malcie, 1.03.2016.

EU-Turkey joint action plan (2015), Brussels, 15 October 2015, http://europa.eu/rapid/press-release_ MEMO-15-5860_en.htm, 1.03.2016.

Flow Monitoring Compilation, Mixed Migration Flows in the Mediterranean and Beyon, Reporting Period 28 JAN - 03 FEB 2016 (2016), https://www.iom.int/sites/default/files/situation_reports/ file/Mixed-Flows-in-the-Mediterranean-and-Beyond-4February2016.pdf, 5.03.2016.

Global Approach to Migration and Mobility (2016), http://ec.europa.eu/dgs/home-affairs/what-we-do/ policies/international-affairs/global-approach-to-migration/index_en.htm, 20.03.2016.

Główne wyzwania dla UE, migracja oraz sytuacja gospodarcza i społeczna, Parlament 2015 - część I (2015), Bruksela 14.10.2015 r., Eurobarometr Parlamentu Europejskiego (EB/EP 84.1), http://www.europarl.europa.eu/pdf/eurobarometre/2015/2015parlemeter/EB84.1_synt_conso_pl.pdf, 2.02.2016.

Greece and Italy continued to face unprecedented number of migrants in December (2016), http://frontex.europa.eu/news/greece-and-italy-continued-to-face-unprecedented-number-of-migrantsin-december-0BbBRd, 2.02.2016.

High-Level Conference on the Eastern Mediterranean/Western Balkans route-Declaration (2015), Brussels 9 October 2015, http://data.consilium.europa.eu/doc/document/ST-12876-2015-INIT/ en/pdf, 2.02.2016.

Instrument Pomocy dla Uchodźców w Turcji: państwa członkowskie uzgadniajq szczegóty finansowania (2016), http://www.consilium.europa.eu/pl/press/press-releases/2016/02/03-refugeefacility-for-turkey/, 1.03.2016.

Joint Foreign and Home Affairs Council: Ten point action plan on migration (2015), Luxembourg, http://europa.eu/rapid/press-release_IP-15-4813_en.htm, 1.03.2016.

Komunikat Komisji do Parlamentu Europejskiego, Rady, Europejskiego Komitetu Ekonomiczno-SpoŁecznego i Komitetu Regionów. Europejski program w zakresie migracji (2015), Bruksela 13.05.2015 r., http://ec.europa.eu/dgs/home-affairs/what-we-do/policies/european-agendamigration/background-information/docs/communication_on_the_european_agenda_on_migration_pl.pdf, 6.03.2016.

Komunikat Komisji do Parlamentu Europejskiego, Rady, Europejskiego Komitetu Ekonomiczno-Spotecznego i Komitetu Regionów. Plan polityki azylowej: Zintegrowana strategia ochrony na catym obszarze UE (2008), Bruksela 17.06.2008 r., http://eur-lex.europa.eu/legal-content/PL/ TXT/?uri=CELEX:52008DC0360, 1.03.2016.

Komunikat Komisji do Rady i Parlamentu Europejskiego w sprawie ustanowienia wspólnego unijnego programu przesiedleń (2009), Bruksela 2.09.2009 r., http://eur-lex.europa.eu/legal-content/PL/ TXT/?uri=celex:52009DC0447, 1.03.2016.

Komitetu Regionów - Wspólna europejska polityka imigracyjna: zasady, dziatania i narzędzia (2008), Bruksela, 17.06.2008 r., http://eur-lex.europa.eu/legal-content/PL/TXT/?uri=celex:52008DC0359, 4.03.2016.

Konkluzja posiedzenia Rady Europejskiej (2015), Bruksela 26.06.2015 r., http://www.consilium.europa.eu/pl/meetings/european-council/2015/06/25-26/, 4.03.2016.

„Königsteiner Schlüssel”, http://www.bamf.de/DE/Migration/AsylFluechtlinge/Asylverfahren/Verteilung/verteilung-node.html, 3.03.2016. 
Leaders' Meeting on refugee flows along the Western Balkans Route Leaders'Statement (2015), http:// ec.europa.eu/news/2015/docs/leader_statement_final.pdf, 8.02.2016.

Member States' Support to Emergency Relocation Mechanism, Communicated as of 11 Feburary 2016 (2016), http://ec.europa.eu/dgs/home-affairs/what-we-do/policies/european-agenda-migration/ press-material/docs/state_of_play___relocation_en.pdf, 22.02.2016.

Nadzwyczajne posiedzenie Rady Europejskiej (2015), http://www.consilium.europa.eu/pl/press/pressreleases/2015/04/23-special-euco-statement/, 7.03.2016.

Number of non-EU citizens ordered to leave has decreased between 2008 and 2014 (2015), http:// ec.europa.eu/eurostat/statistics-explained/index.php/Statistics_on_enforcement_of_immigration_legislation, 19.02.2016.

Oświadczenie szefów państw i rzadów UE (2016a), Bruksela 8 marca 2016 r., http://www.consilium. europa.eu/pl/press/press-releases/2016/03/07-eu-turkey-meeting-statement/, 10.03.2016.

Oświadczenie UE-Turcja (2016b), Bruksela 18 marca 2016 r., http://www.consilium.europa.eu/pl/ press/press-releases/2016/03/18-eu-turkey-statement/, 27.03.2016.

Outcome of the Council Meeting. 3405th Council meeting Justice and Home Affairs (2015), Brussels 20 July 2015, Council of the European Union 11097/15

Over 3,770 Migrants Have Died Trying to Cross the Mediterranean to Europe in 2015 (2015), IOM, http://www.iom.int/news/over-3770-migrants-have-died-trying-cross-mediterraneaneurope-2015, 5.02.2016.

Plan działania UE w zakresie powrotów. Komunikat Komisji do Parlamentu Europejskiego i Rady (2015), Bruksela dnia 9.09.2015 r., http://ec.europa.eu/dgs/home-affairs/what-we-do/policies/ european-agenda-migration/proposal-implementation-package/docs/communication_from_ the_ec_to_ep_and_council_-_eu_action_plan_on_return_pl.pdf, 2.03.2016.

Postęp w realizacji unijnego programu w zakresie migracji (2015), Bruksela 27.05.2015 r., http://europa.eu/rapid/press-release_IP-15-5039_pl.htm, 8.02.2016.

Po konferencji w Londynie: UE przeznaczy ponad 3 mld EUR na pomoc Syryjczykom w 2016 r., (2016), http://www.consilium.europa.eu/pl/press/press-releases/2016/02/04-eu-pledge-for-syrians/, 4.02.2016

Program Haski: wzmacnianie wolności, bezpieczeństwa i sprawiedliwości w Unii Europejskiej, Dz. U. UE C 2005.53.1.

Rada ds. Wymiaru Sprawiedliwości i Spraw Wewnętrznych (2015), Bruksela 20.07.2015 r., http://www. consilium.europa.eu/pl/meetings/jha/2015/07/20/, 7.02.2016.

Reakcja po ogłoszeniu propozycji UE ws. imigrantów (2015), http://wiadomosci.onet.pl/swiat/reakcjapo-ogloszeniu-propozycji-ue-ws-imigrantow/kb7d3x, 22.09.2015.

Realizacja europejskiego programu w zakresie migracji: Sprawozdania Komisji z postępu prac w Grecji, we Włoszech i na Bałkanach Zachodnich, Komisja Europejska - Komunikat prasowy (2016), Bruksela, 10.02.2016 r., http://europa.eu/rapid/press-release_IP-16-269_pl.htm, 7.03.2016.

Relocation - State of play as of 12 January, s. 7, in: Managing the Refugee Crisis. State of Play and future action (2016), http://ec.europa.eu/dgs/home-affairs/what-we-do/policies/european-agenda-migration/background-information/docs/eam_state_of_play_and_future_actions_20160113_en.pdf, 6.03.2016.

Rezolucja Parlamentu Europejskiego z dnia 18 maja 2010 roku w sprawie ustanowienia wspólnego unijnego programu przesiedleń (2009/2240(INI)), Dz. U. UE C 2011.161E.1

Rozporzadzenie Parlamentu Europejskiego i Rady UE nr 439/2010 z dnia 19 maja 2010 roku w sprawie utworzenia Europejskiego Urzędu Wsparcia w dziedzinie Azylu, Dz. U. UE L 2010.132.11.

The Global Risiks Report 2016. 11th Edition, World Economic Forum (2016), Geneva 2016, http:// www3.weforum.org/docs/GRR/WEF_GRR16.pdf, 6.03.2016.

Third country nationals ordered to leave - annual data (rounded) (2016), Eurostat, http://appsso.eurostat.ec.europa.eu/nui/show.do, 9.03.2016. 
Umverteilung Und Neuansiedlung - aktuelle Stand (2016), Europäische Kommission, Stand: 15 März 2016, http://ec.europa.eu/dgs/home-affairs/what-we-do/policies/european-agenda-migration/ background-information/docs/20160316/relocation_and_resettlement_-_state_of_play_de.pdf, 18.03.2016.

Wersje skonsolidowane Traktatu o Unii Europejskiej i Traktatu o funkcjonowaniu Unii Europejskiej, Dz. U. UE C 2012.326.1.

Włosi wściekli. Relokowano tylko 0,47 proc. uchodźców (2016), http://www.tvn24.pl/wiadomoscize-swiata,2/kryzys-imigracyjny-tylko-190-uchodzcow-relokowanych-z-wloch,608577.html, 6.01.2016.

Załacznik do Komunikatu Komisji do Parlamentu Europejskiego, Rady Europejskiej i Rady. Zarzqdzanie kryzysem zwiqzanym z uchodźcami: stan realizacji działań priorytetowych $w$ ramach Europejskiego programu w zakresie migracji (2015), Bruksela 14.10.2015 r., http:// ec.europa.eu/dgs/home-affairs/what-we-do/policies/european-agenda-migration/proposalimplementation-package/docs/communication_on_eam_state_of_play_20151014_annex_1_ pl.pdf, 20.03.2016.

Załacznik do Decyzji Rady (UE) 2015/1601 z dnia 22 września 2015 roku ustanawiajaca środki tymczasowe w obszarze ochrony międzynarodowej na rzecz Włoch $i$ Grecji, Dz. U. UE L 2015.248.80.

Załaczniki towarzyszqce wnioskowi dotyczqcemu decyzji Rady wprowadzajacej środki przejściowe $w$ dziedzinie ochrony międzynarodowej na korzyść Włoch, Grecji $i$ Wegier (2015), Bruksela 9.09.2015 r., http://ec.europa.eu/dgs/home-affairs/what-we-do/policies/european-agenda-migration/proposal-implementation-package/docs/proposal_for_council_decision_establishing_provisional_measures_in_the_area_of_international_protection_for_it_gr_ and_hu_-_annexe_pl.pdf, 5.03.2016.

Zalecenie Komisji (UE) 2015/914 z dnia 8 czerwca 2015 roku dotyczqce europejskiego programu przesiedleń, Dz. U. UE L 2015.148.32.

\section{Migration crisis in the $\mathbf{E U}$ and ways to resolve it}

\section{Summary}

The subject of the considerations in this paper are the issues related to the activities of the EU to solve the immigration crisis in the period from early 2015 to the end of the first quarter of 2016. This paper describes the phenomenon of immigration into the EU in terms of a quantitative analysis. It highlights the situation in Germany, which is the main destination of potential refugees. The author discusses EU immigration policy and the efforts to solve the immigration crisis (relocation, resettlement, return and cooperation with countries of origin and transit - Turkey, the Western Balkans and Africa). The paper reveals the split in member states and the resulting lack of solidarity in solving the problem.

Key words: immigrants, refugees, immigration crisis, relocation, resettlement, the European Union 
